\title{
Kasabach-Merritt syndrome in an infant with cavernous haemangioma
}

\author{
Halyna Pavlyshyn, Nataliia Luchyshyn \\ Department of Paediatrics \#2, Ivan Horbachevsky Ternopil National Medical University, Ternopil, Ukraine
}

\section{ABSTRACT}

Kasabach-Merritt syndrome (KMS) is a potentially life-threatening consumptive coagulopathy associated with vascular malformations, whereas haemangiomas typically present in infancy, with rapid growth, thoracic location, and complicated clinical course demanding chemotherapy and radiotherapy have rarely been reported. We describe a case of a female infant with cavernous haemangioma of the right chest wall spreading to the pleural space and diaphragm, and complicated by KMS. Our patient presented an inadequate response to treatment with systemic corticosteroids, propranolol, and vincristine. Partial tumour regression and diminish of trapping of platelets in the tumour were achieved after radiotherapy only. The purpose of this report is to increase awareness about KMS, to illustrate the treatment challenges and to provide a basis for clinical decision-making in this rare, life-threatening condition.

\section{KEY WORDS:}

Kasabach-Merritt syndrome, cavernous haemangioma, infant, management.

\section{INTRODUCTION}

Cavernous haemangiomas $(\mathrm{CH})$ are histologically benign and have local growth without the potential for metastasis. They may be clinically manifest or asymptomatic and appear during the second to third weeks of life as bluish, pink, or reddish subcutaneous lesions of any shape that may rapidly increase in size. Although benign, $\mathrm{CH}$ can have aggressive local growth and result in life-threatening Kasabach-Merritt syndrome (KMS) [1]. KMS is characterised by profound thrombocytopaenia, microangiopathic haemolytic anaemia, and consumptive coagulopathy in the setting of a rapidly enlarging vascular tumour. The risk of KMS is greater with increased depth and infiltration of the vascular tumour and with retroperitoneal or intrathoracic involvement [2]. The aims of treatment of KMS are twofold: involution of the tumour and correction of the consumptive coagulopathy. Herein, we report on an infant with KMS and provide a literature review of similar cases.

\section{CASE REPORT}

A three-month-old female infant was admitted to the Emergency Department because of a two-hour history of lethargy and a large area of dark red discoloration of her skin on the abdomen and back. The child's parents noticed firm, purpuric coloured swelling on the right side of the chest, which rapidly increased in size from 2 to $10 \mathrm{~cm}$ within one day (Fig. 1). The lesion was not present at birth and appeared as a small red spot observed by the mother at around the age of one month. The medical history was otherwise unremarkable; in particular, trauma, bleeding manifestations, fever, seizures, and any other acute illnesses were absent. No prior therapy was given.

\section{ADDRESS FOR CORRESPONDENCE:}

Nataliia Luchyshyn, Department of Paediatrics \#2, Ivan Horbachevsky Ternopil National Medical

University, Maidan Voli 1, 46001 Ternopil, Ukraine, ORCID: 0000-0001-5102-1926,

e-mail: luchyshyn@tdmu.edu.ua 


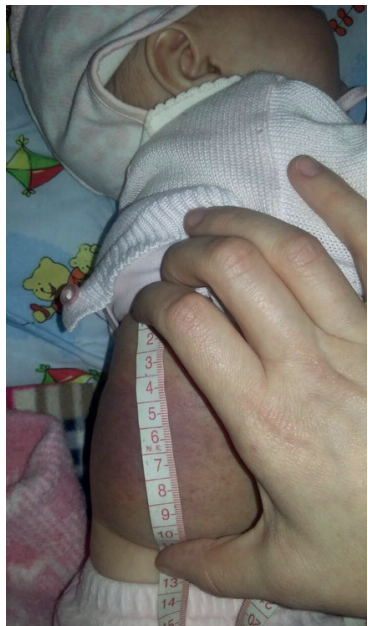

FIGURE 1. A 3-month-old female baby with cavernous haemangioma involving the right side of the chest prior to admission

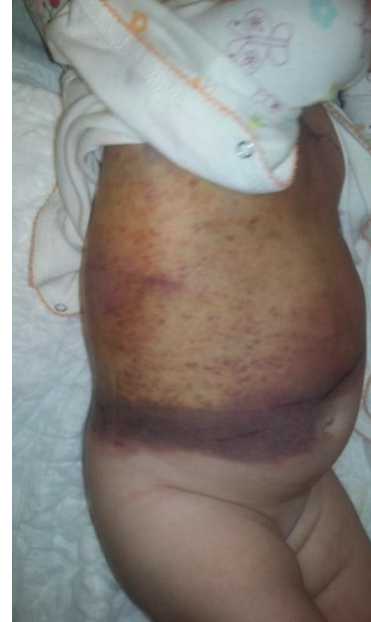

FIGURE 2. The patient on the $3^{\text {rd }}$ day after admission (right side)

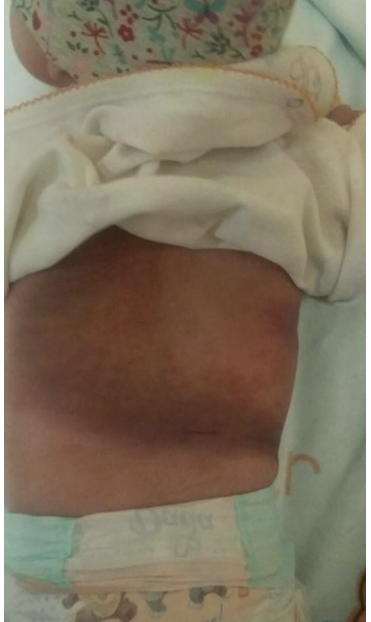

FIGURE 3. The patient on the $3^{\text {rd }}$ day after admission (back side)
At admission, the physical exam revealed an asymmetric massive bruise in the right lateral thoracoabdominal region spreading to the back and a well-bordered tumour mass $10 \mathrm{~cm} \times 8 \mathrm{~cm}$ in size with erythematous appearance, firm consistency, and normal local temperature (Figs. 2 and 3). The liver was palpable $3 \mathrm{~cm}$ below the costal margin (liver span $8.8 \mathrm{~cm}$ ), and the spleen was not palpable. The child did not have any other congenital malformation. Cardiovascular system examination results were normal. Respiratory system examination revealed decreased breathing sounds over the right lung. A plain chest X-ray revealed pleural effusion and compressed right lung (Fig. 4). The complete blood counts at admission revealed haemoglobin of $90 \mathrm{~g} / \mathrm{l}$, white blood cells of $6.5 \times 10^{9} / 1$, platelet counts of $40 \times 10^{9} / 1$, prothrombin time of 15.3 seconds, and partial thromboplastin time of 37 seconds.

Computed tomography (CT) scan of the chest with intravenous contrast revealed tangled blood vessel masses of about $3.3 \mathrm{~cm} \times 1.1 \mathrm{~cm} \times 3.0 \mathrm{~cm}$ in the subcutaneous tissue of the right lateral chest wall with spread to the $9^{\text {th }}-11^{\text {th }}$ intercostal spaces $(2.2 \mathrm{~cm} \times 1.2 \mathrm{~cm} \times 2.6 \mathrm{~cm})$, indicating that the mass could be a haemangioma. The haemangioma was supplied by the right lateral thoracic artery and the 8 th, 9 th, and $10^{\text {th }}$ intercostal arteries. The extravasation of the contrast agent was not demonstrated. CT also demonstrated a pleural effusion $(150 \mathrm{ml})$ with compressed right lung parenchyma and lateral thoracic and abdominal wall muscle infiltration by the haemangioma. In the context of thrombocytopaenia, coagulopathy, and right-sided thoracic cavernous haemangioma, the patient was diagnosed with KMS. She received prednisone $(1 \mathrm{mg} / \mathrm{kg})$, propranolol (2 mg/kg), fresh frozen plasma, platelet transfusion, and chest tube placement. Due to progressive coagulopathy despite all the above treatments, we added intravenous vincristine at a dose of $0.05 \mathrm{mg} / \mathrm{kg} / \mathrm{week}$. The response to four doses of vincristine was poor. Magnetic resonance imaging (MRI) revealed a further increase in the size of the haemangioma (about $5.7 \mathrm{~cm} \times 7.4 \mathrm{~cm} \times 3.5 \mathrm{~cm}$ ). The next step of the treatment was radiotherapy - a total of four sessions with a total dose of $8 \mathrm{~Gy}$ in single-fraction doses of $1 \mathrm{~Gy}$. After the second session, the haemangioma slowly diminished in size. A follow-up MRI performed three months later revealed a further reduction of the tumour mass (tumour volume of $28 \mathrm{~cm}^{3}$ compared to the initial tumour volume of $102 \mathrm{~cm}^{3}$ ). Currently, the girl is under the constant care of oncological and haematological counselling, and the coagulopathy subsided and never recurred after the tumour size was reduced.

\section{DISCUSSION}

Cavernous haemangiomas $(\mathrm{CH})$ are non-infiltrative, low-flow hamartomas that are usually thought to be be-

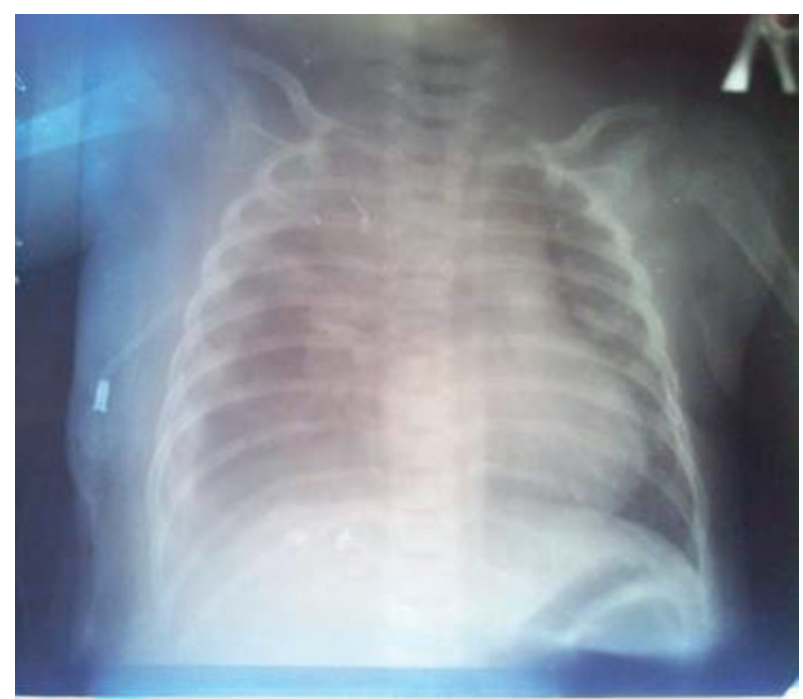

FIGURE 4. Chest X-ray revealed pleural effusion and compressed lung in the right side 
nign [3]. $\mathrm{CH}$ are frequently located in the liver, skin, and subcutaneous tissues, and some have rare locations [4]. Less than $1 \%$ of all haemangiomas are deep-seated, such as intramuscular haemangiomas [5]. Although the $\mathrm{CH}$ is benign and composed of haphazardly arranged vascular tissue, life-threatening complications have been reported in many cases $[2,3,6-8]$. The exact mechanisms that control the involution of haemangiomas are poorly understood. However, the progressive nature of the disorder with some features associated with the patient's growth makes the pathogenic mechanisms age dependent. In some cases, these haemangiomas do not respond to steroids, radiation therapy, cytotoxic drugs, or embolisation [6]. Occasionally it can endanger vital structures and is associated with consumption coagulopathy and thrombocytopaenia, known as KMS [9]. KMS usually develops in infancy, and it is usually associated with kaposiform haemangioendothelioma and tufted angioma, rather than the classic haemangioma of infancy [10]. It is not clear if there is any linear relation to the size of the haemangioma and the initiation of KMS, but most of the KMS cases are reported in giant haemangiomas [11]. Whether a specific organ system (or site) which harbours the haemangioma confers increased predilection towards initiating KMS is also unclear [12]. On reviewing the literature, a wait-and-see strategy is mainly indicated in stable haemangiomas in non-vital sites, without significant impact on appearance and function [9]. The treatment of KMS in the case of $\mathrm{CH}$ is very challenging and involves a two-pronged approach that includes supporting and stabilising haemostasis while trying to remove or ablate the lesion. Management of coagulopathy and supportive care consists of judicious use of platelet transfusion [13], sparing and limited correction of hypofibrinogenaemia and coagulopathy using cryoprecipitate and fresh frozen plasma. However, Wang and Li reported that transfused platelets can release pro-angiogenic growth factors and may stimulate endothelial proliferation and contribute to the late response of vincristine [14]. Corticosteroids are the commonly accepted first-line treatment, but satisfactory results are reported in only $30 \%$ of cases of KMS [15]. Although the mechanisms of steroid therapy are unclear, prednisone appears to increase vasoconstriction, inhibit fibrinolysis (by inhibiting the production of tissue plasminogen activators and increasing the plasminogen activator inhibitors), increase platelet longevity, and disrupt angiogenesis [8]. If no response is seen within a week or two after starting the therapy, then either the dose is increased or alternative therapy is recommended [12]. In other case reports, the authors successfully used orally administered propranolol as monotherapy or in combination with other therapeutic modalities [16-19] with rapidly replaced systemic corticosteroids as first-line therapy for complicated haemangiomas of infancy [20,21]. There are case reports of successful treatment of KMS with vin- cristine and interferon $\alpha[6,9]$. Tumour eradication can be achieved by different techniques: surgery, vascular embolisation, and radiation. Zheng et al. found laser therapy to be unsuitable for the management of deep-seated haemangiomas and rarely used today because of the high incidence of scar formation and poor effects [22]. Fawcett et al. described vascular tumour regression after direct intralesional injection of absolute ethanol. This method is considered to be a simple and reliable alternative treatment for KMS among infants [15]. The use of radiation therapy has also been reported in KMS. However, radiation may have long-term complications, including growth arrest, developmental delay, and secondary malignancies, and should be used with caution in younger patients [22]. Despite the advent of improved imaging and treatment modalities, the cure rate remains suboptimal for most types of vascular malformations. Moreover, long-term relief of symptoms and tumour shrinkage in the majority of patients treated with radiotherapy for large unresectable haemangiomas $[23,24]$ and for life-threatening haemangiomas was confirmed [25]. Master et al. recommended a combination of vincristine and radiation therapy along with supportive care in very symptomatic patients or in cases associated with severe thrombocytopaenia, as an effective initial approach [9]. Some authors have suggested stepwise and individual models for the treatment of KMS in children.

\section{CONCLUSIONS}

Although basic diagnostic criteria for KMS are well known, the management is very challenging because of its rarity and unstandardised therapeutic strategies. Many potent chemotherapeutic agents and approaches can be used, but the response is variable and not always predictable. Considering the fact that the treatment of KMS is still empirical, it is extremely important to publish individual experiences in the management of this life-threatening syndrome. The use of interventional radiology guided therapies has been described with diverse clinical benefits. Nevertheless, in our case radiotherapy proved to be an effective treatment for KMS associated with cavernous haemangioma.

\section{ACKNOWLEDGMENTS}

The authors would like to express their gratitude to Prof. Milen Minkov, MD, Ph.D. for valuable discussions, advice, and assistance, which greatly improved the manuscript. The authors appreciate the consent of the parents of this case.

\section{DISCLOSURE}

The authors declare no conflict of interest. 


\section{REFERENCES}

1. Osifo OD, Evbuomwan I. Hemangiomas in Children: Challenges and Outcome of Surgical Management in Benin City, Nigeria. Iran J Pediatr 2011; 21: 350-356.

2. Schmid I, Klenk AK, Sparber-Sauer M, et al. Kaposiform hemangioendothelioma in children: a benign vascular tumor with multiple treatment options. World J Pediatr 2018; 14: 322-329.

3. Evagelidou E, Tsanou E, Asproudis I, et al. Orbital cavernous hemangioma in an infant with intracranial lesions: a case report. Cases J 2009; 2: 6912.

4. Kaneko K, Kanai R. Cavernous hemangioma of the accessory parotid gland. J Craniofac Surg 2011; 22: e28-29.

5. Wierzbicki JM, Henderson JH, Scarborough MT, et al. Intramuscular hemangiomas. Sports Health 2013; 5: 448-454.

6. Hatley RM, Sabio H, Howell CG, et al. Successful management of an infant with a giant hemangioma of the retroperitoneum and Kasabach-Merritt syndrome with alpha-interferon. J Pediatr Surg 1993; 28: 1356-1357.

7. Szlachetka DM. Kasabach-Merritt syndrome: a case review. Neonatal Netw 1998; 17: 7-15

8. Yadav D, Maheshwari A, Aneja S, et al. Neonatal Kasabach-Merritt phenomenon. Indian J Med Paediatr Oncol 2011; 32: 238-241.

9. Master S, Kallam D, El-Osta H, Peddi P. Clinical Review: Management of Adult Kasabach-Merritt Syndrome Associated with Hemangiomas. J Blood Disord Transfus 2017; 8: 397.

10. Kim JA, Choi YB, Yi ES, et al. Excellent outcome of medical treatment for Kasabach-Merritt syndrome: a single-center experience. Blood Res 2016; 51: 256-260.

11. Ettlinger JJ, Fleming PJ, Joffe HS, Kennedy CT. Cavernous haemangioma with Kasabach-Merritt syndrome: treatment with alphainterferon. J R Soc Med 1996; 89: 55-56.

12. Hall DG. Kasabach-Merritt syndrome: Pathogenesis and management. Br J Hematol 2001; 112: 851-862.

13. Phillips WG, Marsden JR. Kasabach-Merritt syndrome exacerbated by platelet transfusion. J R Soc Med 1993; 86: 231-232.

14. Wang Z, Li K. Treatment of Kasabach-Merritt phenomenon. J Pediatr 2016; 170: 345.

15. Fawcett SL, Grant I, Hall PN, et al. Vincristine as a treatment for a large haemangioma threatening vital functions. J Plast Reconstr Aesthet Surg 2004; 57: 168-171.

16. Cichy B. Skuteczność propranololu w leczeniu naczyniaka niemowlęcego i naczyniakowatości limfatycznej. Pediatr Pol 2011; 86: 372-375.

17. Rodriguez V, Lee A, Witman PM, Anderson PA. Kasabach-Merritt phenomenon: case series and retrospective review of the mayo clinic experience. J Pediatr Hematol Oncol 2009; 31: 522-526.

18. Tang LY, Hing JW, Tang JY, et al. Predicting complications with pretreatment testing in infantile haemangioma treated with oral propranolol. Br J Ophthalmol 2016; 100: 902-906.

19. Zhang L, Wu HW, Yuan W, Zheng JW. Propranolol therapy for infantile hemangioma: our experience. Drug Des Devel Ther 2017; 11: 1401-1408.

20. Oksiuta M, Matuszczak E, Dębek W, et al. Successful exclusive propranolol therapy in an infant with life-threatening Kasabach-Merritt syndrome. J Pediatr Surg Case Rep 2013; 1: 200-202.

21. Harrison P, Nguyen BA, Pickrell BB, Wright TS. Beta-Blockers as Therapy for Infantile Hemangiomas. Semin Plast Surg 2014; 28: 87-90.

22. Zheng JW, Zhang L, Zhou Q, et al. A practical guide to the treatment of infantile hemangiomas of the head and neck. Int J Clin Exp Med 2013; 6: 851-860.
23. Schild SE, Buskirk SJ, Frick LM, Cupps RE. Radiotherapy for large symptomatic hemangiomas. Int J Radiat Oncol Biol Phys 1991; 21: 729-735.

24. Vakilha M, Farhan F, Samiei F, Shariat S. Intramuscular hemangioma of the forearm; Report of a case Iran. J Radiat Res 2003; 1: 175-179.

25. Ogino I, Torikai K, Kobayasi S, et al. Radiation therapy for life- or function-threatening infant hemangioma. Radiology 2001; 218: 834-839. 